\title{
Editorial
}

\section{Ergonomics-Follow and Keep Well}

Mohammed Emran.

DOI: https://doi.org/10.3329/kyamcj.v11i2.48414.

It is an old term. Everybody knows, follows less and suffers much. Here is to remind again.

Greek, "Ergon" means work, and "Nomos" means natural laws or systems. By definition, Ergonomics is the scientific discipline concerned with understanding of the interaction among humans and other elements of an organization or system, and the profession that applies application, theory, data and methods to design in order to optimize human wellbeing and overall system performance. ${ }^{1}$

It deals with adjusting the work environment, tools, task, and equipment to fit with the employees' physical capability and limitations. That is "fitting the task to the worker".

Ergonomics was studied and practiced way back when humans started designing and making things for their use, for example, the chair. The term ergonomics officially proposed at a meeting of the British Admiralty on July 12, 1949 by Prof. Hugh Murrell and accepted in 1950. ${ }^{3}$

There is lack of awareness, knowledge \& practice of ergonomics has been reflected in different studies worldwide. As a result, Globally, the number of people suffering from musculoskeletal conditions has increased and contributing in the global disease as well as cost burden., ${ }^{2,-7}$

Certain physical arrangements increase work-related musculoskeletal disorders (WMSDs). That is injuries or disorders of the muscles, nerves, tendons, joints, cartilage, and spinal discs associated with exposure to ergonomic risk factors in the workplace. ${ }^{8,9}$

Physicians are no different from the general population. Privilege of their medical training does not provide immunity from illness. Among the physicians, musculoskeletal complaints seemed high. The frequently reported prevalence for hand and wrist pain was $8-33 \%, 0-17 \%$ for shoulder pain, and $9-28 \%$ for neck pain, low back pain was between 33 and $68 \%$ and forearm pain to be $25 \%$. $^{10,11}$

Ergonomics intervention program is very much effective in preventing and managing the WMSD. It is successful in reducing the number of WMSDs by over $50 \%$. Moreover, Ergonomics establishes a safe, healthy and comfortable working environment, thereby preventing health problems and improving work efficiency. ${ }^{12-15}$
So, there is need of awareness, knowledge and practice of appropriate ergonomics and postural health.

Healthcare system in Bangladesh has been investing a considerable sum of money for the development of hospital facilities, medical education, computerization of healthcare delivery system, but corresponding resources are not allocated to ensure ergonomic workstations in hospitals, educating and building awareness about ergonomics.

Occupational health services should initiate ergonomic assessment of workstations and implement measures to promote health in Bangladesh. Instructions and guidelines must be a part of public health education programs.

\section{References}

1. International Ergonomics Association. Definition and domains of ergonomics. 2015 July; Available at http://www.iea.cc/whats/index.Html.

2. Ismaila S.O. A Study on Ergonomics Awareness in Nigeria. Australian Journal of Basic and Applied Sciences 2010; 4(5): 731-734.

3. Ergoweb, 2016, History of ergonomics. Available at: http://www.ergoweb.com/knowledge/ergonomics101/history.

4. Khan R, Surti A, Rehman R, Ali U. Knowledge and practices of ergonomics in computer users. Journal of Pakistan Medical Association 2012; 62(3): 213-217.

5. Oladeinde BH, Ekejindu IM, Omoregie R, Aguh OD (2015). Awareness and knowledge of ergonomics among Medical Laboratory Scientists in Nigeria. Annals of medical and health sciences research 2015; 5(6): 423-427.

6. Sarfraz M, Kashmala FS, Farooqi SI, Anees S. (2013). Awareness of Ergonomics among the Physiotherapy and Medical Students. Pakistan Journal of Rehabilitation 2013; 2(1): 31-37.

7. Jamison DT, Breman JG, Measham AR, Alleyne G, Claeson M, Evans DB et al. Disease control priorities in developing countries $2^{\text {nd }}$ ed. Geneva: World Bank Publications; 2006. 23-45.

8. Foley BS. Occupational Rehabilitation. In: Braddom RL, editor. Physical Medicine and Rehabilitation $4^{\text {th }}$ ed. United States: Elsevier Saunders; 2011. 1031-1039. 
9. Bureau of labor statistics, 2013, Nonfatal Occupational Injuries and Illnesses Requiring Days Away From Work Available at: http://www.bls.gov/iif/oshcdnew.htm.pdf

10. Karen M, Hengel O, Visser B, Judith K, Sluiter. The prevalence and incidence of musculoskeletal symptoms among hospital physicians: a systematic review. International Archives of Occupational and Environmental Health 2011; 84(2): 115-119.

11. Johnston WK, Hollenbeck BK, Wolf JS. Comparison of neuromuscular injuries to the surgeon during handassisted and standard laparoscopic urologic surgery. Journal Endouro 2005; 19(3): 377-381.
12. Gatty CM, Turner M, Buitendrop DJ, Batman H. The effectiveness of back pain and injury prevention programs in the workplace. WORK 2002; 20(3): 257-266.

13. Mahmud N, Kenny DT, Zein RM, Hassan SN. Ergonomic training reduces musculoskeletal disorders among office workers: results from the 6-month follow-up. Malaysian Journal of Medical Sciences 2011; 18(2): 16-26.

14. Zalk DM. Grassroots ergonomics: initiating an ergonomics program utilizing participatory techniques. The Annals of Occupational Hygiene 2001; 45(4): 283289.

15. Karibasappa GN, Anandan S, Rajeshwari K. Dentists' Knowledge, Attitude and Behavior towards the Dental Ergonomics. Journal of Dental and Medical Sciences 2014; 13(5): 86-89.

Dr. Mohammed Emran

Department of Physical Medicine and Rehabilitation Member Editorial Board,

KYAMC Journal. 